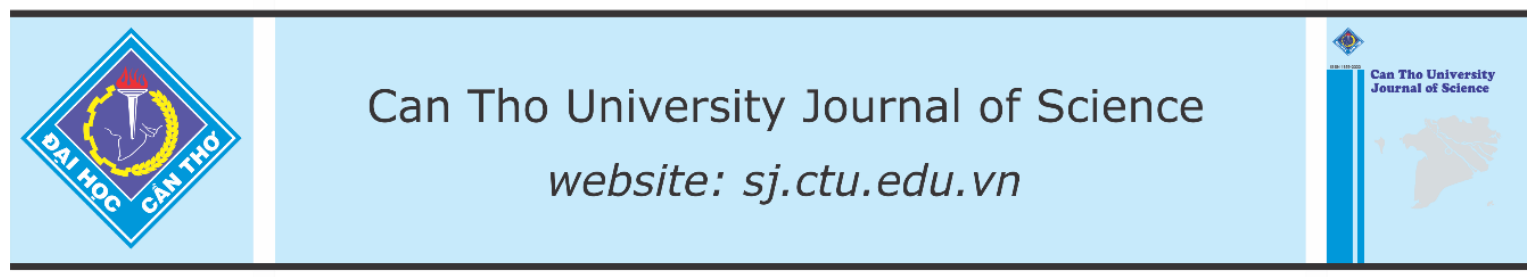

DOI: 10.22144/ctu.jen.2020.012

\title{
Employability attributes of interpretation and translation students in Vietnam
}

\author{
Phuong Hoang Yen* and Huynh Van Hien \\ School of Foreign Languages, Can Tho University, Vietnam \\ *Correspondence: Phuong Hoang Yen (email: phyen@ctu.edu.vn)
}

\section{Article info.}

Received 21 Mar 2020

Revised 11 May 2020

Accepted 31 Jul 2020

\section{Keywords}

Employability, English translation and interpretation, graduate attributes

\begin{abstract}
Universities need to capture the current state of graduate employability from graduates' perspectives if they are to respond effectively to skills and knowledge requirements of the industry. Globally, graduate employability is a concept that is becoming increasingly popular in higher education sector. Therefore, this paper explores employability attributes that graduates of English translation and interpretation (ETI) program need. A survey with 48 ETI alumni of a university in the Mekong Delta of Vietnam reveals the attributes that are important for the job market and those that graduates need more training on. The findings revealed that ETI students not only need to reinforce their English linguistic knowledge, professional knowledge and other skills and knowledge provided in the training program, but also have to develop 'key' employability skills such as, communication, social and cultural skills in order to be ready for the labor market.
\end{abstract}

Cited as: Yen, P.H. and Hien, H.V., 2020. Employability attributes of interpretation and translation students in Vietnam. Can Tho University Journal of Science. 12(2): 25-32.

\section{INTRODUCTION}

Graduate employability (GE) patterns seem to have changed worldwide (Tran, 2016). The labor market has become flexible and competitive. These changes are caused by the expansion of the global economy, globalization as well as the expansion of higher education (HE) provision, which are influencing the hiring demands of employers (Al-Harthi, 2011; Cai, 2013). For employers, the decision to recruit a graduate is based on the qualities and competencies of the graduate student in addition to discipline-specific skills and knowledge. Brown and Hesketh (cited in Tomlinson, 2008) claim that employers are involved in employment discourse to performative and organizational capabilities, behavioral competence, and the wider range of individual. To this end, students and universities alike have recognized the changing nature of employability patterns, and are trying to incorporate employability attributes in degree program provision (Cai, 2013). This awareness has led to studies to determine which employability attributes (EAs) are sought by employers in a given context.

In Vietnam, as elsewhere, employers' concerns about GE attributes have become more pronounced (Hager and Holland, 2006; Tran and Swierczek, 2009; OECD, 2012). There are claims from different stakeholders, especially employers, that graduate students from universities usually do not fully possess the types of GE attributes essential for the workplace. According to Marope (2006), there is a general impression that most employers are dissatisfied with the quality of HE output. This observation is echoed by the Organization for Economic Co-operation and Development (2012), which states 
that university graduate students are often not adequately prepared for work as well as the training are not relevant to the demands of the workplace. This organization also emphasizes that up to $60 \%$ of Vietnamese graduate students are unable to secure occupation and of those who are employed, many need to be re-trained or even do not work in areas of their major. In reference to HE, Tran and Swierczek (2009) have also identified an important challenge facing human resources development in Vietnam. This challenge includes an inadequate attention paid to the development of GE attributes that has a negative impact on preparedness of university graduate students for high-skilled jobs.

Although employers in Vietnam have raised concerns about the lack of EAs in graduate students, no research has investigated the issue of the EAs that are important and essential for job performance; those attributes that should be included in curriculum; and those in which graduate students need more training. Therefore, the purpose of this study is to analyze the need for graduate attributes (GAs) in Vietnam, as perceived by English Translation and Interpretation (ETI) alumni. The current study therefore, seeks the answers to the following research questions:

1. Which employability attributes do bachelor graduates from the ETI program possess?

2. Which employability attributes should be strengthened in the ETI training program?

\section{LITERATURE REVIEW}

\subsection{Translation and interpretation}

According to Wilss (1982), translation is a transfer process that aims at conversing written source language texts into the equivalent target language texts. That process requires the semantic, syntactic, analytical processing and pragmatic understanding of the source language. In the same vein, Bell (1991) defines it as an expression in another language (the target) of what has been presented in one language (the source), preserving stylistic and semantic equivalences.

Similar to translation, interpretation can have a wide range of meanings for many people based on their training, experience or background in the interpretive profession. According to Nolan (2005), interpretation is a process of transmitting message in which its meaning is best expressed in the speaker's mother tongue while that meaning is best understood in listeners' languages. Besides, MacFarlane
(1994) defines that interpretation is a "process of communication" (cited in Hall and McArthur, 1993). The author also emphasized that as a bridgebuilder between languages, the interpreter supports speakers as well as satisfies the demand of understanding what is being said from listeners.

Translation and interpretation (T\&I) have been paired in most cases but they are not identical. European Commission (2009) and Jones (2002) made very simple clarification of the two terms, indicating that both refer to changing messages from an original language to another language; however, interpretation is in spoken form while translation aims for written language.

\subsection{Employability}

Employability skills are in vogue in higher education context and have intensely been the center of attention in literature since 1980 (Zaharim et al., 2009). However, there is no common definition of this term in the literature. Some studies focus more on student ability to find and maintain a job after graduation as Yorke (2010) supposes that the term "employability" is the ability of graduate students to find and retain a graduate-level job and to move between jobs if required. In the same vein, Hillage and Pollard (1998) defines it as the capability to get initial employment, maintain employment as well as obtain employment if required.

In some other views, employability is referred to as the types of knowledge, skills, understandings or attributes of graduate students. As according to Moreland (2006), it is a set of knowledge, personal attributes and skills, which makes an individual more likely to be successful and secure in their chosen professions to the benefit of themselves, the community, the workforce, and the economy. The skills are assumed not only to help graduates get a good profession, but also to apply more technical skills and specific knowledge in their particular workplaces to achieve one's potential as well as contribute successfully to enterprise strategic directions (Australian Chamber of Commerce and Industry \& Business Council of Australia, 2002; UK Commission for Employment and Skills, 2009). In the same vein, the definition of York (2006) seems to be the most comprehensive to the content of the current study. He defines the term "employability" is... a set of achievement - skills, understandings and personal attributes - that makes graduates more likely to gain employment and be successful in their chosen occupations, which benefits themselves, the workforce, the community and the economy (p. 8). 
Although different in wording, all of these definitions relate employability to a set of attributes or skills that are necessary for every graduate to move into the job market, to find as well as maintain jobs and to develop their occupations.

\subsection{Graduate attributes}

In literature, graduate attributes (GAs) are variously referred to as generic attributes (Wright, 1995), employability skills, and soft skills (BIHECC, 2007), key competencies (Mayer, 1992), transferable skills (Assiter, 1995), key skills (Drew et al., 2002).

In the rapid change of the information and knowledge-intensive economy, workers not only need to maintain and develop skills and knowledge, which are specific to their own discipline and occupation, but also have to achieve "generic" skills, attributes and dispositions that are transferable to lots of occupational situations. These generic skills are defined as "those transferable skills which are essential for employability at some level for most" (Kearns, 2001). Generic skills have also been variously known as 'core skills', 'key competencies', 'transferable skills' or 'underpinning skills' (Mayer, 1992).

According to Wickramasinghe and Perera (2010), employability skills are comprised of two main aspects: transferrable skills and subject or disciplinespecific skills. The authors assert that subject skills are key to occupations of graduates since they are skills and discipline-specific knowledge. The professional knowledge is sometimes also considered a type of skill, called technical skills (AC Nielsen Research Services, 2000; World Bank, 2011). However, they are differentiated from generic skills. While technical skills often refer to generic skills, discipline-based skills and capacity as described by Andrews and Higson (2008), consist of areas as working under pressure, coping with uncertainty, planning and strategic thinking, reliability, teamwork and networking, communications and interpersonal interactions, writing and speaking, willingness to learn and acceptance of responsibility, creativity, self-confidence, self-management as well as time-management and information technology skills. Besides, Wickramasinghe and Perera (2010) also show that transferable skills are the competencies that graduates can apply in various job roles and occupations through the graduates' professions. All of skills like writing skills (e.g. punctuation, spelling, grammar), visual communication, oral communication, information skills, solving prob- lems, working with others, career management, information technology (IT) or working with numbers are identified as key skills by Drew et al. (2002).

Several countries have adopted more proactive strategies in enhancing GAs. For instance, the Danish Qualifications Framework demands the researchoriented bachelor's or master's courses to have a competence profile while in Australia there are many "generally accepted" GAs, which universities are demanded to enhance in their graduates. In Canada and the United States, the primary mechanisms for emphasizing GAs are work-based and work-related learning as well as portfolios (Harvey and Bowers-Brown, 2004/2005).

In short, GAs are emphasized in higher education as incentives to attract both employers and learners. GAs are viewed as increasingly essential in the changing context of contemporary life. Moreover, they are considered important to make graduates prepared and ready for success in the rapid change of working environment today.

\subsection{Higher education and employability}

Obtaining a university diploma is not eligible to obtain an occupation (Harvey, 2002). In fact, there are a range of external and person-centered factors which provide a conceptual foundation of employability such as gender or ethnicity, age, personal attributes of open-mindedness, empathy, flexibility, and external factors like the sector- or regionspecific economic situations that have a strong impact on recruitment and employability. In the field of T\&I, the above-mentioned factors should not be ignored. According to Harvey (2002), program areas tend to be more active in promoting employment because their aim is to enhance particular employability attributes or because of a demand to ensure engagement with the professional world.

Nowadays, there are many debates about whether to put more theoretical or applied curricular emphasis on education of T\&I. Therefore, to bridge the gap between workplace reality and academia and reconcile the perspective of universities and employers, bringing the employers' requirements into the analysis of the competencies is essential to make graduates employable. Sine employers are the ones who directly evaluate the professional performance of graduates, their perceptions may provide universities with valuable insights for improving employability through the enhancement of generic and subject specific competencies. According to Weinert (2001), competence is a specialized system of 
proficiencies, abilities or skills that are necessary to reach a specific goal as well as to have various capacities, aptitudes, personal attributes when performing translation tasks in a professional setting.

Garcés and Toudic (2012) reveal that the capability to produce, define or apply quality procedures, the capability to translate the materials in one or more highly specialized fields, the awareness of professional ethics and standards, the capability to use translation memory systems, as well as the capability to extract and manage terminology are the capabilities required by T\&I employers. In addition, many researchers (Hillage and Pollard, 1998; Sewell and Pool, 2010) also suppose that some other important aspects: knowledge, attitude and skills; that is to say more accurately, disciplinary content knowledge, generic (transferable) competencies, soft skills (personal attributes), disciplinary competencies and skills. These employment assets are complemented by job seeking as well as job-maintaining skills or profession management skills. Schnell and Rodríguez (2017) also state that applying the above-mentioned employment assets to the domain of T\&I as well as drawing on the specific and generic competencies will help graduates to find occupations in T\&I field.

\section{THE STUDY}

\subsection{The context}

The study was conducted at a university in the center of the Mekong Delta of Vietnam. Being a multidisciplinary university, the institution provides 99 bachelor programs, 48 master programs and 19 doctorate programs. The Bachelor Program of English Translation and Interpretation (ETI) is administered by the School of Foreign Languages of the institution and follows a credit-based system of 140 credits and consists of three main groups of knowledge namely general knowledge, fundamental knowledge, and domain-specific knowledge. There are 38 credits in the first group which consists of courses: Physical Education, Marxism-Leninism, National Defense Education, French and so on. In the second group, there are 48 credits and include courses with the aim of equipping students with English language knowledge of grammar and pronunciation as well as language skills like listening, speaking, reading and writing. Fifty-four credits in the last group are aimed to provide students with specialized knowledge of English language, literature, and culture as well as useful skills for future jobs and life-long learning such as translating, interpreting and researching.

\subsection{The participants}

A group of 48 alumni of the ETI training program at the institute took part in the study. There are 18 males and 30 females ranging from 24 to 30 years old. At the time of the study, almost all of them (97\%) graduated from the program from one to five years. The alumni were expected to provide useful information of what their employers have expected from them. In the current study, these alumni were purposefully selected for their willingness to participate. Table 1 presents the personal information of the alumni involving in the current study.

\subsection{The questionnaire}

The current study uses a questionnaire as the key research instrument. The questionnaire was adapted from the one used in the study by Álvarez-Álvarez and Arnáiz-Uzquiza's (2017). The adaptations are in conjunction with the ETI curriculum framework used at the university being investigated. The questionnaire was selected because it reports "practical components" of employability which have not been embedded in undergraduate T\&I curriculum, leaving a gap between the actual requirements of employers and the academic dimension of training.

The questionnaire has two main sections. The first section of the questionnaire has four parts in which Part 1 the tasks that explores the alumni are required to perform at their workplace, Part 2 investigates knowledge and skills that they were provided at school, Part 3 finds out their suggestions on skills and knowledge to be strengthened, and Part 4 asks for demographic information.

\section{FINDINGS AND DISCUSSION}

\subsection{Tasks performed by EIT alumni at workplace}

The alumni have been required to do different kinds of tasks (Table 2). The two most common tasks, surprisingly, seem not closely related to the discipline of ETI since writing English documents (77.1\%) and communicating with clients by English (75\%) are two types of tasks that can be done by students of English majors in general and do not require specialized knowledge and skills of interpretation or translation. The next five common tasks conducted by the alumni participants include translating documents from English to Vietnamese (66.7\%); translating documents from Vietnamese to English (62.5\%); doing administrative tasks (62.5\%); interpreting conversations, meetings, events, etc. (54.2\%); and reviewing texts written in English 
$(52.1 \%)$. It can be seen that translating and interpreting occupied a large part of the job duties although the former is more frequent than the latter. However, administrative tasks still take a larger portion than interpreting ones. The two least popular tasks among the alumni participants are reviewing translation works performed by translation tools $(31.3 \%)$ and being a language consultant for colleagues $(12.5 \%)$.

Table 2: Tasks performed by interns at workplace

\begin{tabular}{lrr}
\hline Tasks & Number & Percentage (\%) \\
\hline Writing English documents (reports, business letters, emails, etc.). & 37 & 77.1 \\
Communicating with clients by English. & 36 & 75.0 \\
Translating documents from English to Vietnamese. & 32 & 66.7 \\
Translating documents from Vietnamese to English. & 30 & 62.5 \\
Doing administrative tasks. & 30 & 62.5 \\
Interpreting conversations, meetings, events, etc. & 26 & 54.2 \\
Reviewing texts written in English. & 25 & 52.1 \\
Reviewing translation works performed by translation tools. & 15 & 31.3 \\
Being a language consultant for colleagues. & 6 & 12.5 \\
\hline
\end{tabular}

Table 2 shows that many companies today seem to assign employees to not only tasks that they have been trained at school. Instead, employees, like in the case of the current study, have to be able to cover a variety of tasks, including both the trained and the untrained ones. Therefore, students need to be equipped with life-long learning skills to be ready for different requirements at work.

\subsection{Employability attributes provided at school}

Table 3 reveals the employability attributes that the alumni participants have been trained at school. Among the eleven items listed, English linguistic knowledge is agreed by almost all (45/46) participants to be provided at the training program at the university. The next four common types of knowledge and skills that the alumni claim they have been provided are discipline-specific knowledge (66.7\%); knowledge on strategies for translation (60.4\%); knowledge and skills about revising and editing final translation products (60.4\%); and social skills including teamwork, negotiation and dealing with clients, etc. (58.3\%). In addition, the program has provided Vietnamese linguistic knowledge; cultural knowledge; and computer skills for office work with $56.3 \%, 52.1 \%$ and $45.8 \%$ of agreement, respectively. In addition, about one-third of the participants claim that they have been provided with knowledge and skills to use ETI software, strategies for interpretation, and knowledge on how to write technical documents.

Table 3: Employability attributes that the alumni were provided at school

\begin{tabular}{lrr}
\hline Employability attribute & Frequency & Percentage (\%) \\
\hline English linguistic knowledge & 45 & 93.8 \\
Professional knowledge & 32 & 66.7 \\
Knowledge on strategies for translation & 29 & 60.4 \\
Knowledge and skills about revising and editing final translation & 29 & 60.4 \\
products & 28 & 58.3 \\
Social skills (teamwork, negotiation and dealing with clients, etc.) & 27 & 56.3 \\
Vietnamese linguistic knowledge & 25 & 52.1 \\
Cultural knowledge & 22 & 45.8 \\
Computer skills for office work & 15 & 31.3 \\
Knowledge and skills to use ETI softwares (software for localiza- & 15 & 31.3 \\
tion, audiovisual translation, terminology management, etc.) & 13 & 27.1 \\
Knowledge about strategies for interpretation & & \\
Knowledge on writing technical documents & & \\
\hline
\end{tabular}




\subsection{Employability attributes needed to be strengthened}

With their own experiences at work, the alumni participants suggest the employability attributes that the university should focus more on helping learners of ETI be ready for work (Table 3). Two most important skills are social skills and computer skills with $72.9 \%$ and $64.6 \%$ of agreement, respectively. It seems that the current training program has not provided the alumni with sufficient skills for working with others and computers. In addition, more than $60 \%$ of the participants claim that they need to be provided with more cultural knowledge, knowledge and skills to use ETI software, and professional knowledge in the ETI training program. Moreover, from 50 to $58.3 \%$ of the participants want to be provided with more knowledge and skills of the ones they have been trained at school before.

\section{Table 4: Employability attributes strengthened in the future training program}

\begin{tabular}{lrr}
\hline Employability attribute & Frequency & Percentage (\%) \\
\hline Social skills (teamwork, negotiation and dealing with clients, etc.) & 35 & 72.9 \\
Computer skills for office work (Excel, Word, etc.) & 31 & 64.6 \\
Cultural knowledge & 30 & 62.5 \\
Knowledge and skills to use ETI softwares (software for localiza- & 29 & 60.4 \\
tion, audiovisual translation, terminology management, etc.) & 29 & 60.4 \\
Professional knowledge & 28 & 58.3 \\
Knowledge about strategies for interpretation & 27 & 56.3 \\
Knowledge on writing technical texts & 26 & 54.2 \\
Knowledge on strategies for translation & 25 & 52.1 \\
Knowledge and skills for revising and editing final translation prod- & 24 & 50.0 \\
ucts & 24 & 50.0 \\
English linguistic knowledge & 24 \\
Vietnamese linguistic knowledge & & \\
\hline
\end{tabular}

\subsection{Discussion}

Regarding the participants' perception of EIT curriculum, these findings are similar to the research of Álvarez-Álvarez and Arnáiz-Uzquiza (2017). Almost $90 \%$ of the graduates in their research are conscious of the demand to improve their professional skills. Meanwhile, the findings of Schnell and Rodríguezs' study (2017) indicated that students need to possess the disciplinary knowledge and specific competencies of T\&I.

In addition, the current study is compatible with the findings in Harvey's studies in 2002 and 2005. These studies revealed that ETI program should not only provide students with a diploma in ETI but also train them to be effective learners and workers, with interactive and personal attributes (e.g., teamwork and interpersonal skills or communication). Although these attributes are the "key" employability competences (Drew et al., 2002; Álvarez-Álvarez \& Arnáiz-Uzquiza, 2017), they are not commonly included in the university curriculum (Chouc and Calvo, 2011). Similarly, many previous studies (e.g. Wilss, 1982; Bell, 1991; Nolan, 2005) share the same findings with the present one. Those studies suggest that mother tongue's linguistic knowledge should be strengthened in the training program to help students transmit messages accurately and clearly without violating professional ethics. In addition, in the same vein with Bui and Dang's (1997) recommendations, the participants in the current study suggest strengthening knowledge on strategies for translation and interpretation in the ETI curriculum.

Nevertheless, there are also differences between the current study and other previous ones. In the current study, cultural knowledge is one of the most essential criteria, which should be provided in the ETI curriculum. Participants suppose knowledge on cultural diversities is significant for communication with people of diverse custom, race, and ethnicity. It is regarded as the key to successful communication, as Alred and Byram (2002) indicated. Schell and Rodríguez (2017) show that the vast majority of the respondents focus more on general and specialized translation skills than others.

\section{CONCLUSIONS}

The current study was conducted to investigate the employability attributes which employers require for bachelor graduates from ETI program. The participants also give some suggestions for improving the current curriculum to enhance students' employability. The findings of the current study show that 
ETI students not only need to reinforce their English linguistic knowledge, professional knowledge and other skills and knowledge provided in the training program, but also have to develop 'key' employability skills (e.g. social and cultural skills, as well as communication skills) which are not commonly included in the university curriculum (Chouc and Calvo, 2011). Therefore, it is suggested that curriculum designers should take the requirements of the labor market into consideration to improve students' employability.

\section{REFERENCES}

AC Nielsen Research Services, 2000. Employer satisfaction with graduate skills: Research report. Canberra: Department of Education, Training and Youth Affairs.

Al-Harthi, K., 2011. University student perceptions of the relationship between university education and the labour market in Egypt and Oman. Prospects. 41(4): 535-551.

Alred, G., Byram, and M., 2002. Becoming an intercultural mediator. Journal of Multilingual \& Multicultural Development. 23(5): 339-352.

Álvarez-Álvarez, S., and Arnáiz-Uzquiza, V., 2017. Translation and interpreting graduates under construction: do Spanish translation and interpreting studies curricula answer the challenges of employability? The Interpreter and Translator Trainer. 11(23): 139-159.

Andrews, J., and Higson, H., 2008. Graduate employability, 'soft skills' versus 'hard' business knowledge: A European study. Higher Education in Europe. 33(4): 411-422.

Assiter, A., 1995. Transferable skills: A response to the sceptics. In A. Assiter (Ed.). Transferable skills in higher education. London. Kogan Page: 11-20.

Bell, R. T., 1991. Translation and Training Theory and Practice. Longman. New York. 298 pages.

Brown, P., and Hesketh, A. J. 2004. The mismanagement of talent: Employability and jobs in the knowledge economy. Oxford: Oxford University Press.

BIHECC (Business, Industry and Higher Education Collaboration Council), 2007. Graduate employability skills. Graduate employability skills report. Accessed on Jan. 15, 2020. Available from http://www.dest.gov.au/sectors/higher_education/programmes_funding/programme_categories/key_priorities/documents/graduate_employability_skills_pdf.htm.

Cai, Y., 2013. Graduate employability: A conceptual framework for understanding employers' perceptions. Higher Education. 65(1): 457-469.

Chouc, F., and Calvo, E., 2011. Embedding employability in the curriculum and building bridges between academia and the workplace: A critical analysis of two approaches. Accessed on Jan. 15, 2020. Available from http://www.lalinternadeltraductor.org/n4/employability-curriculum.html.

Drew, S., Thorpe, L., and Bannister, P., 2002. Key skills computerized assessments: Guiding principles. Assessment and Evaluation in Higher Education. 27(2): 175-186.

European Commission, 2009. Translation and interpreting: Languages in action. Luxembourg: Office for Official Publications of the European. 17 pages.

Garcés, V. C., and Toudic, D., 2012. Technological innovation and translation. Training translators in the EU for the 21st century. Accessed on Jan. 15, 2020. Available from https://www.ucjc.edu/wp-content/uploads/11.Carmen-Valero-Garces-y-DanielToudic.pdf.

Hager, P., and Holland, S., 2006. Graduate attributes learning and employability. Dordrecht, The Netherlands. Springer.

Hall, M., and McArthur, S., 1993. Heritage Management in Australia and New Zealand: The Human Dimension. Australia. Oxford University Press.

Harvey, L., 2002. Employability and diversity. Centre for research and evaluation, Sheffield Hallam University. Accessed on Jan. 15, 2020. Available from https://www.qualityresearchinternational.com/esecttools/relatedpubs/enhancingemployabilityrecdiversity.pdf.

Harvey, L., 2005. Embedding and integrating employability. New Directions for Institutional Research, 2005(128): 13-28.

Harvey, L., and Bowers-Brown, T., 2004/2005, Winter. Employability cross country comparison. Graduate Market Trends: 3-5.

Hillage, J., and Pollard, E., 1998. Employability: Developing a framework for policy analysis. London. Department for Education and Employment.

Jones, E., 2002. Interpreters and Translators. Occupational Outlook Quarterly, 2, 22-29. Accessed on Jan. 15, 2020. Available from https://www.bls.gov/careeroutlook/2002/summer/art02.pdf.

Kearns, P., 2001. Generic skills for the new economy review of research. Adelaide. National Centre for Vocational Education Research.

Marope, T., 2006. Namibia human capital and knowledge development for economic growth with equity. Africa Region Human Development. Working Paper Series No. 84. Accessed on Jan. 15, 2020. Available from http://siteresources.worldbank.org/INTAFRICA/Resources/No84.pdf.

Mayer, E., 1992. Putting education to work: The key competencies report. Melbourne. Australian Education Council and Ministers of Vocational Education, Employment and Training. 
Moreland, N., 2006. Entrepreneurship and higher education: An employability perspective. Heslington, York: Enhancing Student Employability Co-ordination Team, ESECT.

Nolan, J., 2005. Interpretation Techniques and Exercises. Multilingual Matters Ltd. Toronto.

OECD (Organization for Economic Cooperation and Development), 2012. South East Asian Economic Outlook. Paris. OECD.

Schnell, B., and Rodríguez, N., 2017. Ivory tower vs. workplace reality. Employability and the T\&I curriculum - balancing academic education and vocational requirements: a study from the employers' perspective. Published online: 12 Jul 2017. Accessed on Jan. 15, 2020. Available from file:///D:/CAO\%20HOC/lv\%20moi/B\%C3\%81O/TR ANSLATION/Ivory\%20tower\%20vs\%20workplace\%20reality.pdf.

Sewell, P., and Pool. D. L., 2010. Moving from conceptual ambiguity to operational clarity: employability, enterprise and entrepreneurship in higher education. Education + Training, 52(1): 89-94.

Tomlinson, M., 2008. 'The degree is not enough': Students' perceptions of the role of higher education credentials for graduate work and employability. British Journal of Sociology of Education, 29(1): 49-61.

Tran, Q. T., and Swierczek, F. W., 2009. Skills development in higher education in Vietnam. Asia Pacific Business Review, 15(4), 565-586.
Tran, T. T., 2016. Enhancing graduate employability and the need for university-enterprise collaboration. Journal of Teaching and Learning for Graduate Employability, 7(1): 58-71.

UK Commission for Employment and Skills, 2009. Employee demand for skills: A review of evidence and policy - Executive summary. London. WM Enterprise and Employment Research Institute, Edinburgh Napier University.

Weinert, F. E., 2001. Concept of competence: A conceptual clarification. In D.S. Rychen, L. H. Salganik (Eds.), Defining and selecting key competencies: 45-65.

Wickramasinghe, V., and Perera, L., 2010. Employers' perceptions towards employability skills. Education + Training, 52(3): 226-244.

Wilss, W. 1982. The Science of Translation. Stuttgart: Gunter Narr verlag Tubingen.

Wright, P., 1995. What are graduates? Clarifying the attributes of "graduateness." The Higher Education Quality Council (HEQC): Quality Enhancement Group. Accessed on Jan. 15, 2020. Available from http://www.city.londonmet.ac.uk/deliberations/graduates/starter.html

Yorke, M., 2010. Employability: Aligning the message, the medium and academic values. Journal of Teaching and Learning for Graduate Employability, 1(1): 2-12.

Zaharim, A., Yusoff, Y. M., Omar, M. Z., Mohamed, A., and Muhamad, N., 2009. Engineering employability skills required by employers in Asia paper presented at the 6th WSEAS International Conference on engineering education. Rodos. Greece. 